\title{
Inspection of Phytochemical Content and In Vitro Antioxidant Profile of Gnaphalium Iuteoalbum L.: An Unexplored Phytomedicine
}

\author{
Md. Sahab Uddin ${ }^{1, *}$, G.M. Sala Uddin ${ }^{1}$, Mst. Marium Begum², Yesmin Begum ${ }^{1}$, Oscar \\ Herrera-Calderon ${ }^{3}$, Md. Manjurul Islam ${ }^{4}$ and Mohamed M. Abdel-Daim ${ }^{5}$ \\ ${ }^{1}$ Department of Pharmacy, Southeast University, Dhaka, Bangladesh \\ ${ }^{2}$ Department of Pharmacy, East West University, Dhaka, Bangladesh \\ ${ }^{3}$ Academic Department of Pharmaceutical Sciences, Faculty of Pharmacy and Biochemistry, Universidad \\ Nacional San Luis Gonzaga de Ica, Ica, Peru \\ ${ }^{4}$ Department of Pharmacy, University of Development Alternative, Dhaka, Bangladesh \\ ${ }^{5}$ Pharmacology Department, Faculty of Veterinary Medicine, Suez Canal University, Ismailia, Egypt
}

\begin{abstract}
Background: Oxidative stress is intensely linked with several pathological manifestations. Searching for medicinal plant with the superior safety profile for the treatment of oxidative stress related disorders are ongoing due to multiple unwanted effects associated with synthetic antioxidants. Therefore the purpose of this study was to examine the phytochemical content, in vitro antioxidant potentiality of crude methanol extract (CME), carbon tetrachloride fraction (CTF), petroleum ether fraction (PEF), chloroform fraction (CLF) and ethyl acetate fraction (EAF) of aerial parts of Gnaphalium Iuteoalbum (GL) L.
\end{abstract}

Methods: The aerial parts of the GL were extracted with methanol followed by fractionation using carbon tetrachloride petroleum ether, chloroform and ethyl acetate. The phytochemical screening of this plant was performed by using standard methods to evaluate the existence of alkaloids, carbohydrates, phenols, flavonoids, saponins, tannins, terpenoids and fixed oils. Antioxidant potentiality was estimated by, 2,2-diphenyl-1-picrylhydrazyl (DPPH), hydroxyl (OH) and nitric oxide (NO) radical scavenging tests. Total antioxidant capacity (TAC), total phenolic content (TPC) and total flavonoid content (TFC) were also measured.

Results: Phytochemical analysis of the aerial parts of GL confirmed the presence of carbohydrates, phenols, flavonoids and saponins in crude extract and its all fractions. The CME showed the highest scavenging activity $(43.28 \%)$ with $I_{50}$ of $398.49 \mu \mathrm{g} / \mathrm{mL}$ in the DPPH radical scavenging test. The $\mathrm{IC}_{50}$ values of EAF, CME were statistically significant $(P<0.05$, $\mathrm{P}<0.01)$ with respect to ascorbic acid (ACA). For $\mathrm{OH}$ and $\mathrm{NO}$ radical scavenging tests maximum scavenging $(48.39 \%$, 69.64\%) was also reported for CME compared to CTF, PEF, CLF and EAF. Compared to ACA, in case of OH and NO radical scavenging activities the $I_{50}$ values of $C M E$ were markedly significant $(P<0.01, P<0.05)$. In the TAC test, CME showed the highest antioxidant activity (absorbance, $2.6 \mathrm{~nm}$ ) related to other fractions. TPC was found to be the highest in the CME (115.96 mg of gallic acid equivalent/g of dried extract) rather than other fractions. The ranking order of CTF, PEF, CLF, EAF and CME for TFC was $48.67<55.75<65.29<71.35<82.29 \mathrm{mg}$ quercetin equivalent/g of dried extract.

Conclusion: The existing study suggested that CME of the aerial parts of GL can be used as a natural source of antioxidant which might be effective towards preventing or slowing oxidative stress related disorders.

Keywords: Phytochemical, Antioxidant activity, Gnaphalium luteoalbum, Oxidative stress, Synthetic antioxidants.

\section{INTRODUCTION}

Oxygen is considered as prime oxidant in metabolic reactions in order to obtain energy from the oxidation of a variety of organic molecules required to sustain life [1]. Oxidative stress is the outcome of the metabolic reactions that use oxygen, which is the disturbance in the equilibrium status of pro-oxidant/anti-oxidant systems in cells owing to excess amount of reactive oxygen/nitrogen species (ROS/RNS) [2]. Disturbances

*Address of correspondence to this author at the Department of Pharmacy, Southeast University, Dhaka, Bangladesh; Tel: +880 1710220110/ 1670760546; E-mail: msu-neuropharma@hotmail.com,

msu_neuropharma@hotmail.com in the normal redox state of cells can cause toxic effects through the production of free radicals and peroxides that damage all components of the cell, including proteins, lipids and nucleic acid [3]. Free radicals and other reactive species are supposed to play a key role in oxidative stress that is linked with aging and countless chronic diseases such as atherosclerosis, heart disease, arthritis, gastritis, diabetes, cancer, preeclampsia, acquired immune deficiency syndrome (AIDS), inflammation, ischemia and neurodegenerative diseases especially Alzheimer's disease, Huntington disease, Parkinson disease (PD), amyotrophic lateral sclerosis and celiac diseases [4-7].

(c) 2017 Lifescience Global 
Antioxidants are substances that inhibit oxidative damage of other molecules in biological entities. Antioxidants exert its action by slowing or preventing the oxidation process that can damage cells [8]. In case of countering free radical mediated oxidative stress, antioxidants are considered as crucial while the human body has its endogenous antioxidant defenses against oxidative stress [9]. During aging and or in case of certain illness endogenous antioxidants are not sufficient and required exogenous antioxidants [9, 10]. Although, antioxidants are commercially available as dietary supplements but there is no confirming clinical evidence in support of synthetic antioxidants as useful in keeping healthy and preventing disease [11]. Conversely, the safety of synthetic antioxidants (propyl gallate, butylated hydroxyanisole, butylated hydroxytoluene etc.) is dubious and assumed to be oncogenic [12]. In addition, there is a lot of anecdotal proof that antioxidant-rich medicinal plants/foods are highly effective for protection against neurodegenerative diseases, heart disease, cancer, diabetes, mascular degeneration, etc $[1,13]$.

Phytoconstituents are mainstay for exerting various therapeutic activities and serve as a blueprint for the development of new pharmaceuticals [14]. Worldwide currently, there has been an augmented interest to find antioxidant compounds which are pharmacologically active and have minor or no side effects [15]. Medicinal plants are the greatest source of natural antioxidant. In the developing world, medicinal plants serve as a potential source of primary healthcare needs [16]. The antioxidant activity of medicinal plants are owing to the presence of phytoconstients such as phenolics (polyphenolics) and flavonoids to prevent the oxidative stress caused by ROS/RNS [15, 16]. Complementary and alternative medicine systems including Ayurveda, Unani Chinese and other afford extensive lead to find therapeutically effective antioxidant compounds from medicinal plants [17].

The plant Gnaphalium luteoalbum (GL) L. belongs to the family Asteraceae is known in Bengali as Bara Kamra [18]. This plant is widely distributed all over Bangladesh in fallow lands. It is an annual herb with a height of 15 to $45 \mathrm{~cm}$, stem simple or branched and softly woolly. Leaves are sessile, about 2.5 to $6.3 \mathrm{~cm}$ long, spathulate-oblong or linear oblong, woolly on both surfaces [19]. The flowers of this plant are dense, leafless, corymbose clusters of yellow glistening heads [18]. The leaves of this plant are used as an astringent and vulnerary and the tomentum is applied as a counter irritant for gout [20].
A number of studies suggested that this plant contains glucoside resins, tannins, flavonoids, essential oils, phytosterins, etc [21]. Therefore the intention of this study was to examine phytochemical constituents and in vitro antioxidant activity of crude methanol extract (CME), carbon tetrachloride fraction (CTF), petroleum ether fraction (PEF), chloroform fraction (CLF) and ethyl acetate fraction (EAF) of aerial parts of $\mathrm{GL}$.

\section{MATERIALS AND METHODS}

\section{Chemicals}

2,2-Diphenyl-1-picrylhydrazyl (DPPH), 2-deoxy-2ribose, EDTA (ethylenediaminetetraacetic acid), sulphuric acid, ammonium molybdate, sodium nitroprusside, sulfanilic acid reagent, thiobarbituric acid (TBA), trichloro aceticacid (TCA), Folin-Ciocalteu (FC) reagent, ascorbic acid (ACA), gallic acid (GA) and quercetin (QR) were bought from Sigma-Aldrich, USA. Unless otherwise specified, remaining chemicals were of analytical grade and obtained from native sources.

\section{Collection and Identification of Plant Materials}

The aerial parts of the GL were collected in July, 2016 from Bangladesh National Herbarium, Mirpur, Dhaka, Bangladesh and identified by a skilled taxonomist of the same institute. A voucher specimen with accession number has been deposited in Bangladesh National Herbarium, Dhaka, Bangladesh. The accession number of GL was: DACB-39509.

\section{Drying and Grinding of Plant Materials}

The aerial parts of the plant were washed properly by using water followed by shade drying and irregular sun drying for 10 days. Then dried aerial parts were ground into coarse powder by using a suitable crushing machine. After that generated powder sample was stored in an airtight glass conation until extraction.

\section{Extraction and Fractionation of Plant Materials}

Powdered plant materials (i.e., aerial parts) having a weight of $250 \mathrm{~g}$ was taken in an amber colored glass bottle and soaked in $900 \mathrm{ml}$ of $98 \%$ methanol at $25^{\circ} \mathrm{C}$. The bottle with powder sample was sealed and kept for 7 days with unsystematic agitation at $25^{\circ} \mathrm{C}$. After that the extract was filtered to obtain filtrate and then concentrated by the help of a rotary evaporator at $50^{\circ} \mathrm{C}$ temperatures to give crude methanolic extract (CME). The CME was subjected to fraction, by using carbon tetrachloride (CTF), petroleum ether (PEF), chloroform 
(CLF) and ethyl acetate (EAF) respectively. Then fractionated solvents were evaporated to produce 2.94 $\mathrm{g}, 2.72 \mathrm{~g}, 2.49 \mathrm{~g}$ and $2.15 \mathrm{~g}$ fractions respectively and kept until antioxidant tests.

\section{Phytochemical Analysis}

The phytochemical screening of the crude extract and it's all fractions were determined by using the method as described by Sofowora to detect the presence or absence of secondary metabolites such as alkaloids, carbohydrates, phenols, flavonoids, saponins, tannins, terpenoids and fixed oils [22].

\section{Antioxidant Activity}

To start antioxidant activity a solution of each obtained plant extract/fractions was made by using $95 \%$ methanol at $1 \mathrm{mg} / \mathrm{ml}$ concentration.

\section{DPPH Radical Scavenging Assay}

In line with the method of Choi et al., with minor modifications DPPH radical scavenging activity of the GL was examined [23]. In this test, $2 \mathrm{ml}$ of sample (extract/fractions) at numerous concentrations (i.e., 25 to $400 \mu \mathrm{g} / \mathrm{ml}$ ) was added to $3 \mathrm{ml} 0.02 \%$ of methanol solution of DPPH into the test tubes. To complete the reaction the test tubes were incubated for $30 \mathrm{~min}$ in dark place. Then the absorbance was measured at 517 $\mathrm{nm}$ in contradiction of methanol as blank using UV spectrophotometer. For this test as a standard ascorbic acid (ACA) was used.

The following equation was used to calculate the percent scavenging of the DPPH free radical:

DPPH scavenging $(\%)=\left[1-\left(A / A_{\circ}\right)\right] \times 100$

where, A symbolizes the absorbance of the sample/standard solution and $A_{o}$ symbolizes the absorbance of the control.

\section{Hydroxyl Radical Scavenging Assay}

In line with the method of Elizabeth et al., hydroxyl $(\mathrm{OH})$ radical scavenging activity of the $\mathrm{GL}$ was examined [24]. In this test, $0.1 \mathrm{ml}$ of sample (extract/fractions) at various concentrations (i.e., 25 to $400 \mu \mathrm{g} / \mathrm{ml}$ ) was added to $1 \mathrm{ml}$ of reaction mixture [0.5 $\mathrm{ml}$ of $2.8 \mathrm{mM}$ 2-deoxyribose in a $50 \mathrm{mM}$ phosphate buffer $(\mathrm{pH} 7.4), 0.2 \mathrm{ml}$ of premixed $100 \mu \mathrm{M}$ ferric chloride and100 $\mu \mathrm{M}$ EDTA $(1: 1 ; \mathrm{v} / \mathrm{v}), 0.1 \mathrm{ml}$ of $200 \mathrm{mM}$ hydrogen peroxide and $0.1 \mathrm{ml} 300 \mu \mathrm{M} \mathrm{ACA}$ ] into the test tubes. After an incubation period of $1 \mathrm{~h}$ at $37^{\circ} \mathrm{C}$,
$0.5 \mathrm{ml}$ of the reaction mixture was added to $1 \mathrm{ml} 2.8 \%$ TCA followed by addition of $1 \mathrm{ml} 1 \%$ TBA solution and then the reaction mixture was incubated at $90^{\circ} \mathrm{C}$ for 15 min so that color develop. Then at $25^{\circ} \mathrm{C}$ test tubes were cooled and the absorbance was measured at 532 $\mathrm{nm}$ in contradiction of methanol as blank using UV spectrophotometer. For this test as a standard ACA was used.

The following equation was used to calculate the percent scavenging of the $\mathrm{OH}$ free radical:

$\mathrm{OH}$ radical scavenging $(\%)=\left[1-\left(\mathrm{A} / \mathrm{A}_{\circ}\right)\right] \times 100$

where, A symbolizes the absorbance of the sample/standard solution and $A_{o}$ symbolizes the absorbance of the control.

\section{Nitric Oxide Radical Scavenging Assay}

In line with the method of Rai et al., nitric oxide (NO) radical scavenging activity of the $G L$ was examined [25]. In this test, $0.5 \mathrm{ml}$ of sample (extract/fractions) at various concentrations (i.e., 25 to $400 \mu \mathrm{g} / \mathrm{ml}$ ) was added to $0.5 \mathrm{ml}$ of $10 \mathrm{mM}$ sodium nitroprusside in phosphate buffered-saline into the test tubes. After an incubation period of $150 \mathrm{~min}$ at $25^{\circ} \mathrm{C}$ in the dark, $1 \mathrm{ml}$ of sulfanilic acid reagent $(0.33 \%$ sulfanilic acid in $20 \%$ glacial acetic acid) was added to $0.5 \mathrm{ml}$ of the reaction mixture so that color develop. Then the test tubes were again incubated for $5 \mathrm{~min}$ followed by addition of $1 \mathrm{ml}$ of $0.1 \%$ naphthyl ethylene diamine dihydrochloride and again incubated for $30 \mathrm{~min}$ at $25^{\circ} \mathrm{C}$. Then the absorbance was measured at $540 \mathrm{~nm}$ in contradiction of methanol as blank using UV spectrophotometer. For this test as a standard ACA was used.

The following equation was used to calculate the percent scavenging of the NO free radical:

NO radical scavenging $(\%)=\left[1-\left(A / A_{\circ}\right)\right] \times 100$

where, A symbolizes the absorbance of the sample/standard solution and $A_{o}$ symbolizes the absorbance of the control.

\section{Total Antioxidant Capacity (TAC)}

In line with the method of Prieto et al., with minor modifications TAC of the GL was examined [26]. In this test, $0.5 \mathrm{ml}$ of sample (extract/fractions) at various concentrations (i.e., $100-600 \mu \mathrm{g} / \mathrm{ml}$ ) was added to $3 \mathrm{ml}$ of reaction mixture $(28 \mathrm{mM}$ sodium phosphate, $0.6 \mathrm{M}$ sulphuric acid and $1 \%$ ammonium molybdate) into the test tubes. To complete the reaction the test tubes 
were incubated for $15 \mathrm{~min}$ at $95^{\circ} \mathrm{C}$ in a water bath. Then the test tubes were cooled up to $25^{\circ} \mathrm{C}$ and the absorbance was measured at $695 \mathrm{~nm}$ in contradiction of a reagent blank by the help of UV spectrophotometer. For this test as a standard ACA was used.

\section{Total Phenolic Content (TPC)}

In line with the method as stated by Singleton and Rossi with minor modifications TPC of the GL was examined [27]. In this test $0.1 \mathrm{ml}$ of sample (extract/fractions) with a concentration of $1000 \mu \mathrm{g} / \mathrm{ml}$ was mixed with $0.75 \mathrm{ml}$ of $\mathrm{FC}$ reagent that was previously diluted 1000 -fold by using distilled water into the test tubes. Then for $5 \mathrm{~min}$ the test tubes were incubated at $22^{\circ} \mathrm{C}$ followed by the addition of $0.06 \%$ sodium carbonate solution and again incubated for 90 $\min$ at $22^{\circ} \mathrm{C}$ to complete the reaction. Then the absorbance was measured at $725 \mathrm{~nm}$ in contradiction of a reagent blank by the help of UV spectrophotometer. For this test to estimate TPC gallic acid standard curve was used and results were expressed as $\mathrm{mg}$ of gallic acid equivalents (GAE)/g of dried sample.

\section{Total Flavonoid Content (TFC)}

In line with the method as stated by Chang et al., TFC of GL was examined [28]. In this test $0.1 \mathrm{ml}$ of sample (extract/fractions) with a concentration of 1000 $\mu \mathrm{g} / \mathrm{ml}$ was mixed with $3 \mathrm{ml}$ of methanol, $0.2 \mathrm{ml}$ of $10 \%$ aluminum chloride, $0.2 \mathrm{ml}$ of $1 \mathrm{M}$ potassium acetate and $5.6 \mathrm{ml}$ of distilled water into the test tubes. Then for $25 \mathrm{~min}$ the test tubes were incubated at $25^{\circ} \mathrm{C}$ to complete the reaction and the absorbance was measured at $420 \mathrm{~nm}$ in contradiction of a reagent blank by the help of UV spectrophotometer. For this test to estimate TFC quercetin standard curve was used and results were expressed as $\mathrm{mg}$ of quercetin equivalents $(Q R E) / g$ of dried sample.

\section{Statistical Analysis}

The results were expressed as mean \pm standard deviation (SD) from three diverse observations. For in vitro antioxidant tests, student's t test was used to find the significance of standard and sample in case of $\mathrm{IC}_{50}$. The statistical and graphical analysis was performed by using SPSS 14.0 (Chicago, IL, USA) and Microsoft Excel 2010 (Roselle, IL, USA). The value of $P<0.05$ was considered as significant.

\section{RESULTS}

\section{Determination of Phytochemical Constituents}

Table 1 showed the phytochemical constituents of the GL extract and fractions based on the intensity of the characteristic color. The results confirmed the presence of alkaloids, carbohydrates, phenols, flavonoids, saponins, tannins and terpenoids in CME. Carbohydrates, phenols, flavonoids and saponins were present in CTF, PEF, CLF and EAF.

\section{Determination of DPPH Radical Scavenging Activity}

Figure 1 characterizes the DPPH radical scavenging activity of the GL extract and fractions. The radical scavenging activity of the extract/fractions was in the following order: CTF $<$ PEF $<$ CLF $<$ EAF $<$ CME $<$ ACA. Dose-dependent increase in DPPH radical scavenging activity was reported, i.e., antioxidant activity increased with respect to increased concentration of the extract/fractions. Table 2

Table 1: Phytochemical Constituent of the Aerial Part of GL Extract and Fractions

\begin{tabular}{|c|c|c|c|c|}
\hline Phytochemical Constituents & CTF & PEF & CLF & EAF CME \\
\hline \hline Alkaloids & - & + & + & + \\
\hline Carbohydrates & + & + & ++ & + \\
\hline Phenols & + & + & + & + \\
\hline Flavonoids & + & + & + & ++ \\
\hline Saponins & + & + & + & + \\
\hline Tannins & + & - & + & + \\
\hline Terpenoids & - & + & + & + \\
\hline Fixed oils & + & - & + & + \\
\hline
\end{tabular}

where based on the intensity of the characteristic color, $+=$ Present in mild amount, $++=$ Present in moderate amount, $+++=$ Present in large amount, $-=$ Not present. $\mathrm{CTF}=$ Carbon tetrachloride fraction, $\mathrm{PEF}=$ Petroleum ether fraction, $\mathrm{CLF}=$ Chloroform fraction, $\mathrm{EAF}=\mathrm{Ethyl}$ acetate fraction, $\mathrm{CME}=\mathrm{Crude}$ methanol extract. 


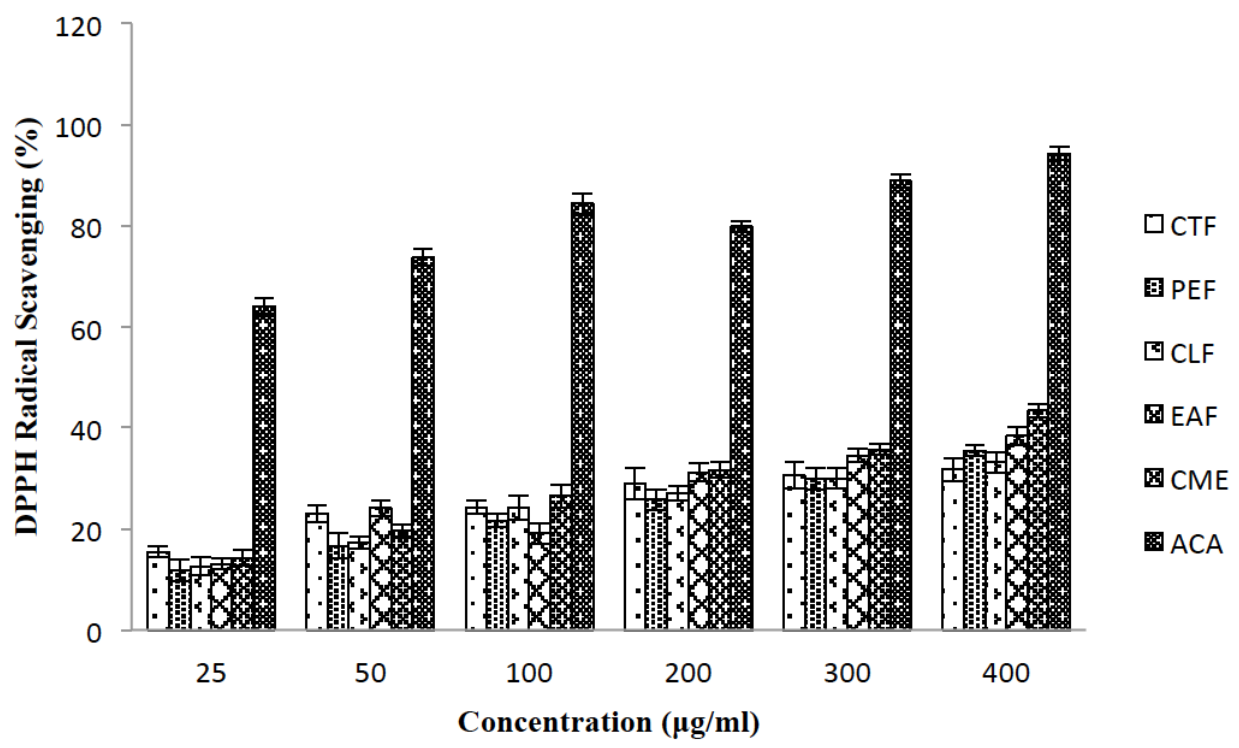

Figure 1: DPPH radical scavenging activity of the aerial part of GL extract and fractions at various concentrations. Values were expressed as mean $\pm S D(n=3)$. CTF = Carbon tetrachloride fraction, PEF = Petroleum ether fraction, CLF = Chloroform fraction, $\mathrm{EAF}=\mathrm{Ethyl}$ acetate fraction, $\mathrm{CME}=$ Crude methanol extract, $\mathrm{ACA}=$ Ascorbic acid .

Table 2: $\quad I_{50}$ Values of the Aerial Part of GL Extract and Fractions for DPPH, OH and NO Radical Scavenging Activity

\begin{tabular}{|c|c|c|c|}
\hline \multirow{2}{*}{ Sample/Standard } & \multicolumn{3}{|c|}{ IC $_{50}(\mu \mathrm{g} / \mathrm{mL})$} \\
\cline { 2 - 4 } & DPPH Radical & OH Radical & NO Radical \\
\hline \hline CTF & $601.33 \pm 2.16$ & $478.37 \pm 3.28$ & $417.38 \pm 2.69$ \\
\hline PEF & $576.78 \pm 3.57$ & $446.56 \pm 4.29$ & $454.73 \pm 4.47$ \\
\hline CLF & $523.59 \pm 3.13$ & $408.92 \pm 2.76$ & $387.49 \pm 3.19$ \\
\hline EAF & $452.14 \pm 2.88^{*}$ & $367.49 \pm 4.25$ & $361.53 \pm 4.42^{*}$ \\
\hline CME & $398.49 \pm 4.12^{* *}$ & $342.23 \pm 3.18^{* *}$ & $47.18 \pm 3.79$ \\
\hline ACA & $32.46 \pm 3.14$ & $38.91 \pm 2.76$ & \\
\hline
\end{tabular}

Values were expressed as mean $\pm \mathrm{SD}(\mathrm{n}=3)$. CTF $=$ Carbon tetrachloride fraction, PEF $=$ Petroleum ether fraction, CLF $=$ Chloroform fraction, EAF $=$ Ethyl acetate fraction, $\mathrm{CME}=$ Crude methanol extract, $\mathrm{ACA}=$ Ascorbic acid. $\mathrm{P}<0.05, " \mathrm{P}<0.01$ significant difference as compared to standard.

represents The $\mathrm{IC}_{50}$ values of $\mathrm{CTF}, \mathrm{PEF}, \mathrm{CLF}, \mathrm{EAF}$, CME and ACA in which $I_{50}$ values of EAF and CME were statistically significant $(P<0.05, P<0.01)$ with respect to ACA.

\section{Determination of OH Radical Scavenging Activity}

The $\mathrm{OH}$ radical scavenging effect of the $\mathrm{GL}$ extract and fractions is given in Figure 2 . The radical scavenging activity was in the following order: CTF < $\mathrm{PEF}<\mathrm{CLF}<\mathrm{EAF}<\mathrm{CME}<\mathrm{ACA}$. The $\mathrm{IC}_{50}$ values of CLF, EF, MNF, CEE and ASC were shown in Table 2. Compared to ACA the $I C_{50}$ value of $C M E$ was statistically significant $(P<0.01)$.

\section{Determination of NO Radical Scavenging Activity}

In Figure 3, NO radical scavenging activity of the GL extract and fractions is stated in the following order: CTF $<$ PEF < CLF < EAF < CME < ACA. The CME showed the highest nitric oxide scavenging activity $(69.64 \%)$ compared to other fractions and the $I_{50}$ value $(361.53 \pm 4.42 \mu \mathrm{g} / \mathrm{ml})$ of this extract was statistically significant $(P<0.05)$ compared to ACA.

\section{Determination of TAC}

Figure 4 represents the TAC of the GL extract and fractions in which the antioxidant activity were in the following order: CTF $<$ PEF $<$ CLF $<$ EAF $<$ CME < ACA. The relationship between antioxidant activity and concentration of the extract and fractions was dosedependent.

\section{Determination of TPC}

TPC of the GL extract and fractions was calculated from the standard curve of gallic acid $(y=0.0158 x+$ $\left.0.0448 ; R^{2}=0.9923\right)$. Among the extract and fraction highest TPC was found in CME compared to the 


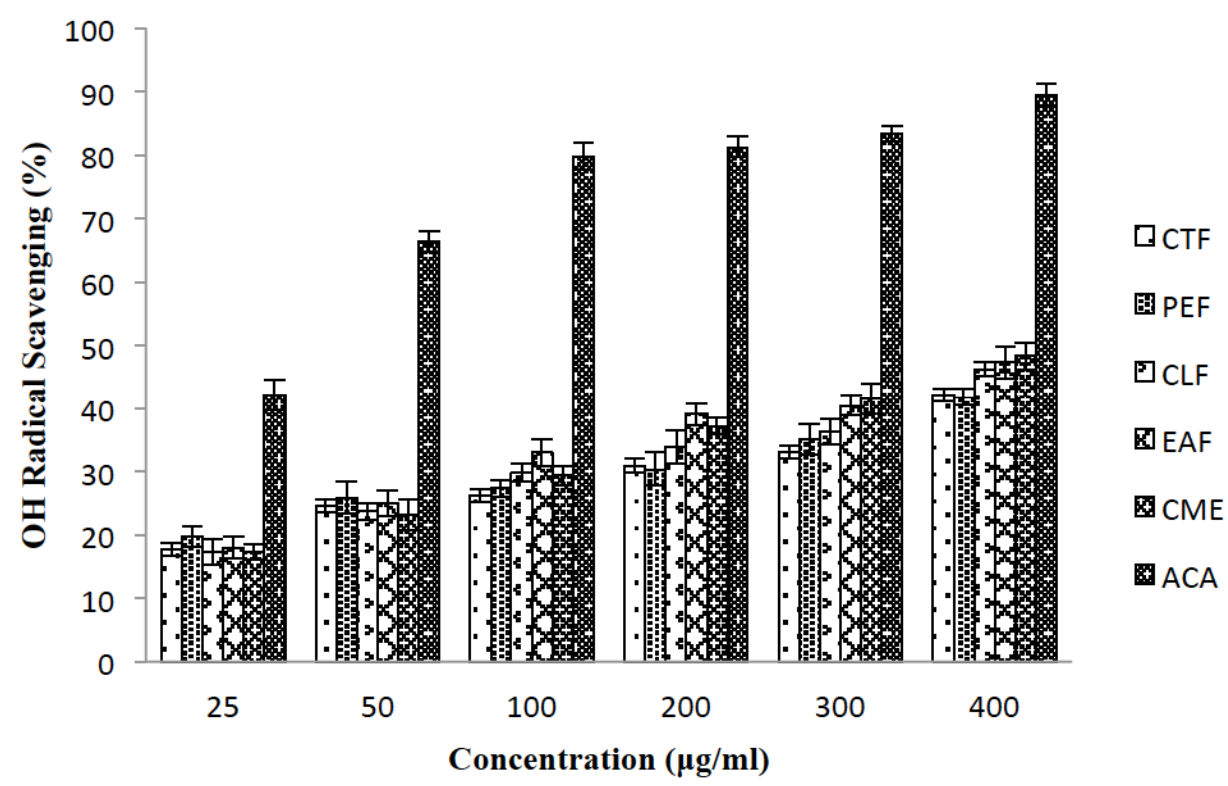

Figure 2: $\mathrm{OH}$ radical scavenging activity of the aerial parts of $\mathrm{GL}$ extract and fractions at various concentrations. Values were expressed as mean \pm SD $(n=3)$. CTF = Carbon tetrachloride fraction, PEF = Petroleum ether fraction, CLF = Chloroform fraction, $\mathrm{EAF}=\mathrm{Ethyl}$ acetate fraction, $\mathrm{CME}=$ Crude methanol extract, $\mathrm{ACA}=$ Ascorbic acid.

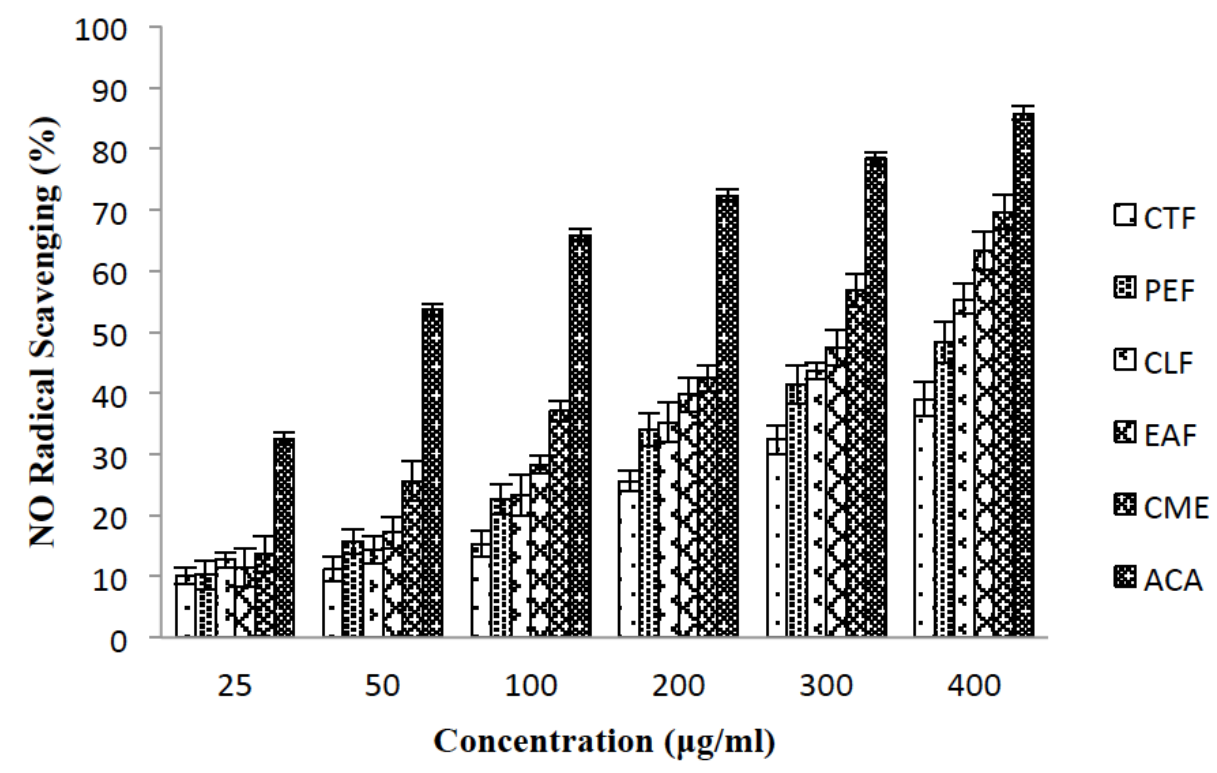

Figure 3: NO radical scavenging activity of the aerial parts of GL extract and fractions at various concentrations. Values were expressed as mean $\pm S D(n=3)$. CTF = Carbon tetrachloride fraction, PEF = Petroleum ether fraction, CLF = Chloroform fraction, $\mathrm{EAF}=\mathrm{Ethyl}$ acetate fraction, $\mathrm{CME}=$ Crude methanol extract, $\mathrm{ACA}=$ Ascorbic acid .

remaining fraction given in Figure 5. The following order was founded based on the outcomes of the given figure: $\mathrm{CTF}<\mathrm{PEF}<\mathrm{CLF}<\mathrm{EAF}<\mathrm{CME}$.

\section{Determination of TFC}

TFC of the GL extract and fractions were calculated from the standard curve of quercetin $(y=0.0098 x+$ $\left.0.1177 ; R^{2}=0.9908\right)$. Figure 6 represents that the TPC were in the following order: CTF $<\mathrm{PEF}<\mathrm{CLF}<\mathrm{EAF}<$ CME. According to this sequence, CME exhibited the highest flavonoid contents than other fractions.

\section{DISCUSSION}

Oxidative stress induced by an increase in free radicals and or decrease in antioxidant defenses is responsible for pathogenesis of various disease states [29]. ROS and RNS play an imperative role in the oxidative stress as specified previously. Recently there has been an upsurge of interest in the therapeutic potential of medicinal plants with antioxidant potency [30]. In the present study, phytochemical content and in vitro antioxidant profiling of GL was carried out by using various tests. 


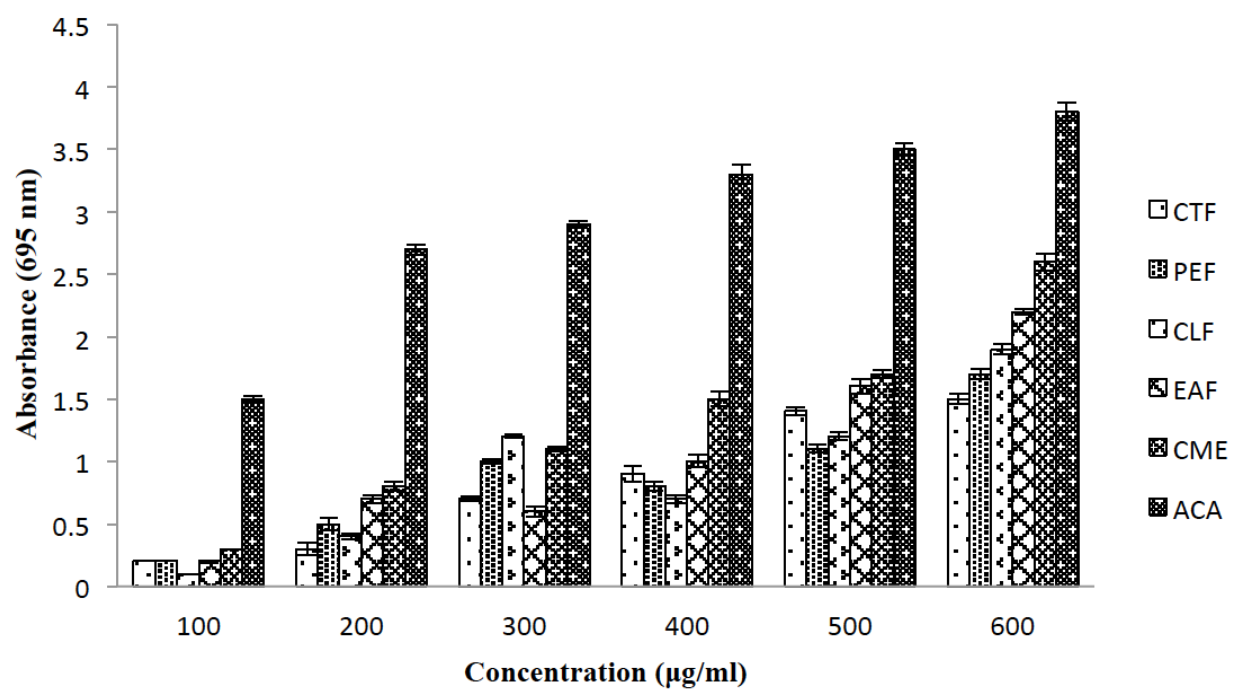

Figure 4: TAC of the aerial parts of GL extract and fractions at various concentrations. Values were expressed as mean \pm SD (n = 3). CTF = Carbon tetrachloride fraction, PEF = Petroleum ether fraction, CLF = Chloroform fraction, EAF = Ethyl acetate fraction, $\mathrm{CME}=$ Crude methanol extract, $\mathrm{ACA}=$ Ascorbic acid.

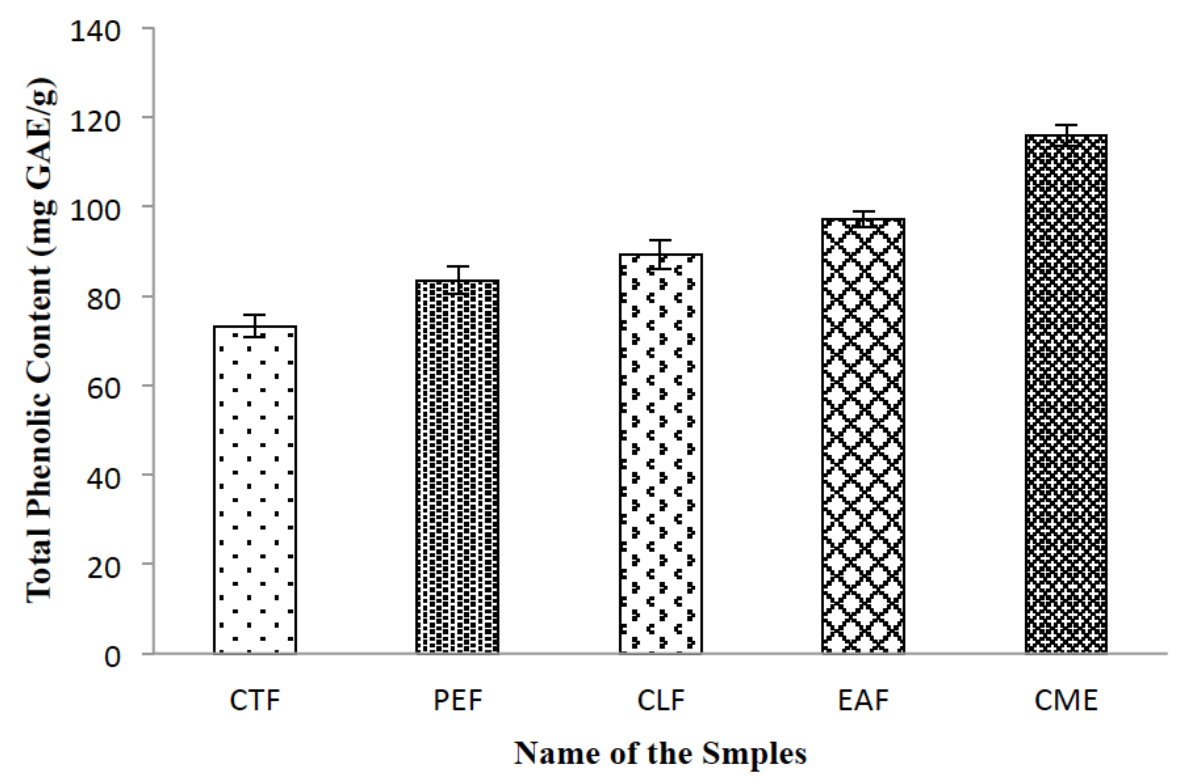

Figure 5: TPC of the aerial parts of GL extract and fractions at various concentrations. Values were expressed as mean \pm SD (n $=3)$. CTF = Carbon tetrachloride fraction, $\mathrm{PEF}=$ Petroleum ether fraction, CLF = Chloroform fraction, EAF = Ethyl acetate fraction, $\mathrm{CME}=$ Crude methanol extract.

The phytochemical screening of crude extract and its fractions revealed a wide range of phytoconstituents such as alkaloids, carbohydrates, phenols, flavonoids, tannins and terpenoids. Among the phytochemicals, phenols, flavonoids, tannins and terpenoids are accountable for antioxidant activities [31]. Phenolic compounds are strong antioxidants responsible for the protection of oxidative damage to biomolecules (i.e., DNA, lipids and proteins) crucial for numerous diseases [32]. The antioxidant properties of phenols are owing to holding one or more aromatic rings with one or more hydroxyl groups [33]. Plant phenolics include phenolic acids, flavonoids, tannins etc. are the abundant secondary metabolite have been connected with multiple biological roles such as free radical scavenger, anti-inflammatory, anticancer, hypoglycaemic, hypocholesterolemic antibacterial, antifungal, antiviral activity, antiparasitic etc. activities [34].

The electron gifting capability of the medicinal plant is most widely determined by DPPH radical scavenging test owing to its reliability [35]. In this test, purplecolored solution of DPPH radical by accepting electrons converted to discolor DPPH-H. In fact the degree of color change is related to the concentration and effectiveness of the antioxidants. The degree of 


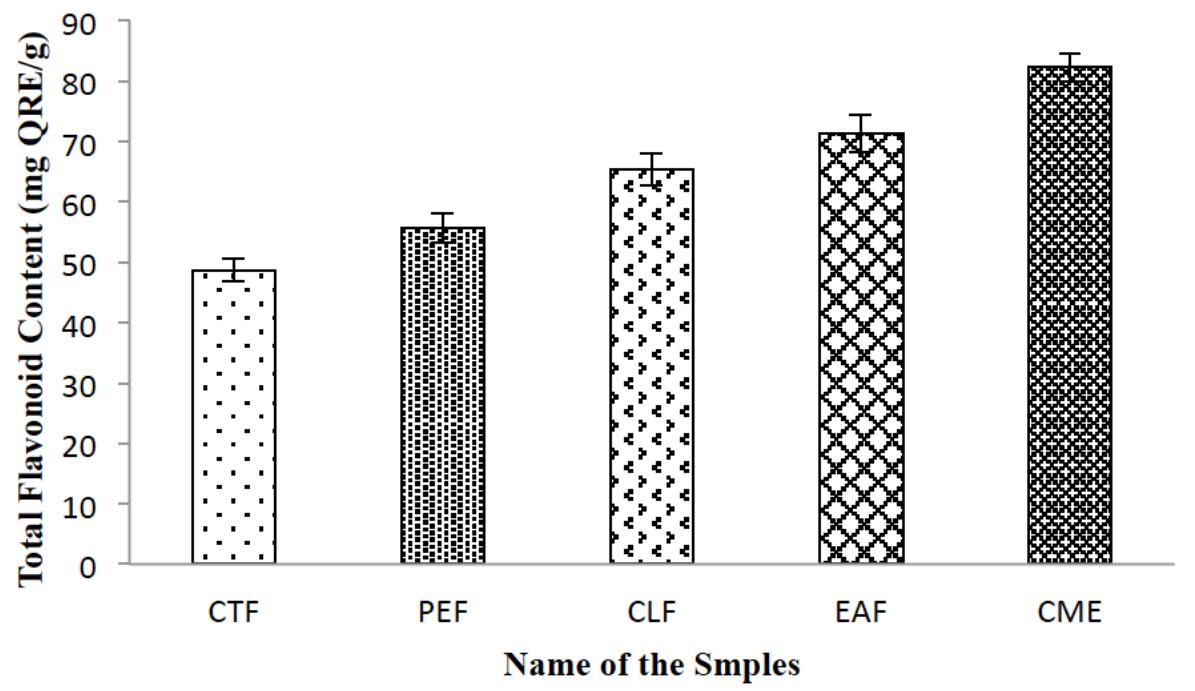

Figure 6: TFC of the aerial parts of GL extract and fractions at various concentrations. Values were expressed as mean \pm SD (n = 3). CTF: Carbon tetrachloride fraction, PEF: Petroleum ether fraction, CLF = Chloroform fraction, EAF = Ethyl acetate fraction, $\mathrm{CME}=$ Crude methanol extract.

discoloration with respect to decrease in the absorbance of the reaction mixture indicates free radical scavenging action [36]. In the study among the extract and fractions tested, CME exhibited higher percentage of scavenging. The study suggests that the plant extract that contains flavonoid and related polyphenols are proficient for donating hydrogen to a free radical to prevent the disease related to free radical mediated oxidative stress [37].

The $\mathrm{OH}$ radical is highly reactive short-lived (approximately $10^{-9} \mathrm{sec}$ ) ROS in the biological system that can damage almost all types of macromolecules: carbohydrates, nucleic acids, lipids and amino acids [38]. $\mathrm{OH}$ radical shows a significant role in the pathogenesis of biological systems and contributes to neurodegeneration, mutagenesis and carcinogenesis [39]. The source of this radical is mainly the decomposition of hydroperoxides, however byproduct of immune action may also contribute [40]. In this test the formation of low intensity of the red color solution indicates $\mathrm{OH}$ radical scavenging power connected to antioxidant capacity. Herein CME showed the highest percentage of scavenging activity compared to remaining fractions. The $\mathrm{OH}$ radical scavenging activity of plant extract is responsible for reduction of lipid peroxidation which is considered as leading causative factor for disease [41].

NO is a free radical generated endogenously in several types of cells [42]. It serves as an important biological messenger (i.e., cellular signaling molecule) involved in many physiological plus pathological processes [43]. A high concentration of NO displays neurotoxicity and can induce apoptotic cell death in different types of neuronal cells. It has been suggested that NO-facilitated neuronal injury is involved in several neuronal disorders such as PD [44, 45]. The results of this study showed the CME has substantial NO radical scavenging activity, compared to remaining factions in a dose-dependent manner. The radical scavenging antioxidant activity of plant extract mainly depends on the presence of phytoconstients especially total polyphenols content [46].

The phosphomolybdate test has usually been used to assess the TAC of medicinal plants [47]. This test is based on reduction of molybdenum (Mo) $(\mathrm{VI})$ to the Mo (V) $[47,4$ 8]. The formation of green phosphate color Mo (V) compounds from Mo (VI) with a maximum absorption at $695 \mathrm{~nm}$ indicates the antioxidant capacity of the plant extract [49]. The existing study confirmed that CME showed the highest antioxidant capacity with respect to remaining fractions. The study recommends that the antioxidant activity of plant extract is noticeable for the presence of bio-active constituents generally polyphenols, tocopherol, carotenoids and ascorbic acid [50].

Phenolic compounds abundant in medicinal plants contribute significantly to the antioxidant properties [51]. The $\mathrm{OH}$ groups and conjugated ring structures of the phenolic compounds is responsible for antioxidant effect by scavenging or stabilizing free radicals through hydrogenation or complexing with oxidizing species [52]. Among the phenolic compounds, flavonoids are chief hydroxylated phenolic compounds [53]. A number of studies reported various pharmacological activities of 
flavonoidic derivatives, including antioxidant, antiinflammatory, analgesic, antibacterial, antiviral, anticancer, anti-allergic, antiobesity, antidiabetic and nootropic actions [54]. In the scavenging of various free radicals, flavonoids are highly effective by their redox potential [55]. There has been increasing interest in the research on flavonoids obtained from plants since pharmacological properties of flavonoids are directly linked with their antioxidant potentiality $[55,56]$. The results of this study endorsed that polyphenolic constituents (i.e., phenolic acids and flavonoids) may be the foremost contributing agents for the antioxidant activity, in this study highest phenolic and flavonoid contents were reported for CME. An earlier study also exposed almost similar findings [57].

This study revealed a potent in vitro antioxidant activity of the aerial parts of $\mathrm{GL}$, which may be an effective source of natural antioxidant.

\section{CONCLUSION}

This study evaluated that the CME of the aerial parts of GL exhibited significant antioxidant activity and contained substantial amount of phenols and flavonoids with respect to remaining fractions. The existing study indorsed the presence of lead compounds in GL. So aerial parts of GL can be a good source of natural antioxidant alternatives, yet further studies will be required to isolate the bioactive compound(s).

$$
\begin{aligned}
& \text { ABBREVIATIONS } \\
& \text { CTF = Carbon tetrachloride fraction } \\
& \text { PEF = Petroleum ether fraction } \\
& \mathrm{CLF} \quad=\text { Chloroform fraction } \\
& \mathrm{EAF}=\text { Ethyl acetate fraction } \\
& \text { CME = Crude methanol extract } \\
& \text { ACA = Ascorbic acid } \\
& \mathrm{GL} \quad=\text { Gnaphalium luteoalbum } \\
& \mathrm{DPPH}=\text { 2,2-Diphenyl-1-picrylhydrazyl } \\
& \mathrm{OH}=\text { Hydroxyl } \\
& \text { NO = Nitric oxide } \\
& \text { TAC = Total antioxidant capacity } \\
& \text { TFC = Total phenolic content }
\end{aligned}
$$

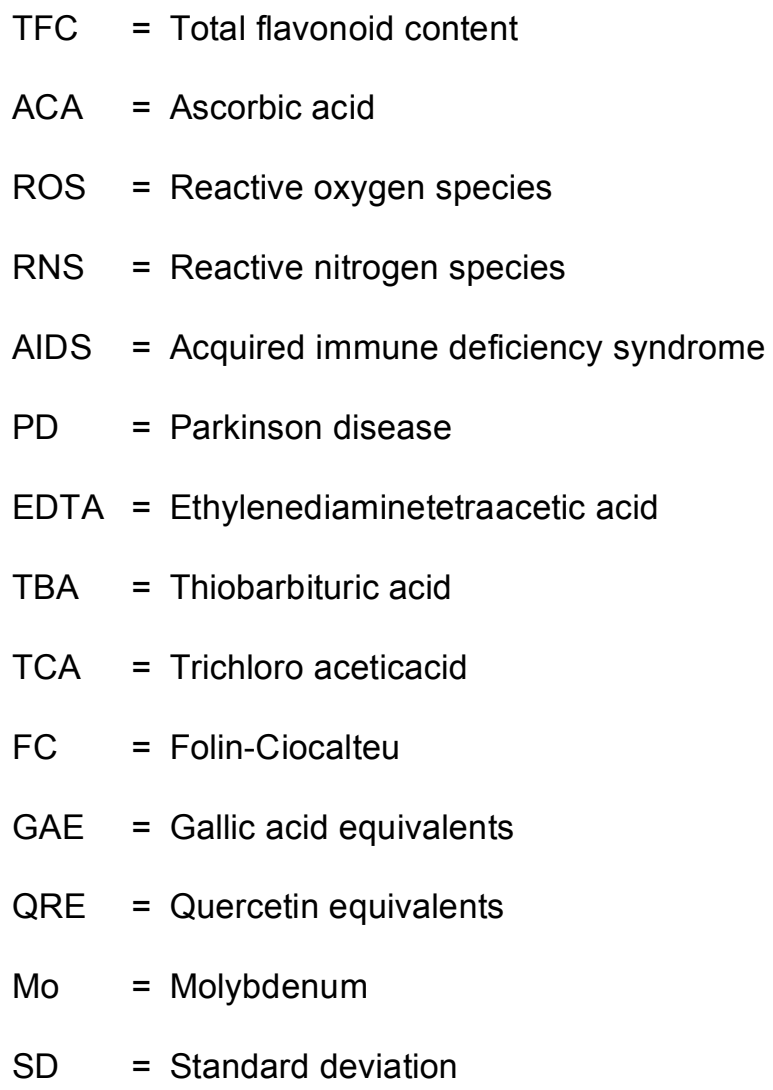

\section{AUTHORS' CONTRIBUTIONS}

This work was carried out in collaboration between all authors. Author MSU designed the study, wrote the protocol, managed the analyses of the study and prepared the draft of the manuscript. Authors MSU, GMSU and MMI carried out the tests. Author MMB performed literature review. Author $\mathrm{OHC}$ performed the statistical analysis. Authors YB and MMAD reviewed the scientific contents of the manuscript. All the authors read and approved the final manuscript.

\section{ACKNOWLEDGEMENTS}

The authors wish to thank the anonymous reviewer(s)/editor(s) of this article for their constructive reviews. The authors are also grateful to the Department of Pharmacy, Southeast University, Dhaka, Bangladesh.

\section{COMPETING INTERESTS}

The authors proclaim that they have no competing interests.

\section{REFERENCES}

[1] Sati SC, Sati N, Rawat U, Sati OP. Medicinal plants as a source of antioxidants. Res J Phytoche 2010; 4: 213-224. https://doi.org/10.3923/riphyto.2010.213.224

[2] Uttara B, Singh AV, Zamboni P, Mahajan RT. Oxidative stress and neurodegenerative diseases: $A$ review of 
upstream and downstream antioxidant therapeutic options. Cur Neuropharmaco 2009; 7: 65-74. https://doi.org/10.2174/157015909787602823

[3] Rahal A, Kumar A, Singh V, Yadav B, Tiwari R, Chakraborty $\mathrm{S}$, et al. Oxidative stress, prooxidants, and antioxidants: the interplay. BioMed Res Int 2014; 2014: 1-7. https://doi.org/10.1155/2014/761264

[4] Barrera G. Oxidative stress and lipid peroxidation products in cancer progression and therapy. Int Scho Rese Net 2012; 2012: $1-10$ https://doi.org/10.5402/2012/137289

[5] Halliwell B. Lipid peroxidation, antioxidants and cardiovascular disease: how should we move forward. Cardio Res 2000; 47: 410-418. https://doi.org/10.1016/S0008-6363(00)00097-3

[6] Uddin MS, Mamun AA, Hossain MS, Akter F, Iqbal MA, Asaduzzaman M. Exploring the effect of Phyllanthus emblica L. on cognitive performance, brain antioxidant markers and acetylcholinesterase activity in rats: Promising natural gift for the mitigation of Alzheimer's disease. Ann Neurosci 2016; 23(4): 218-229.

https://doi.org/10.1159/000449482

[7] Pham-Huy LA, He H, Pham-Huy C. Free radicals, antioxidants in disease and health. Int J Biomed Sci 2008; 4(2): 89-96

[8] Reed TT, Pierce WM, Markesbery WR, Butterfield DA. Proteomic identification of HNE bound proteins in early Alzheimer disease: Insights into the role of lipid peroxidation in the progression of AD. Brain Rese 2009; 1274: 66-76. https://doi.org/10.1016/j.brainres.2009.04.009

[9] Rahman K. Studies on free radicals, antioxidants, and cofactors. Clin Interv Aging 2007; 2(2): 219-236.

[10] Harman D. Aging: A theory based on free radical and radiation chemistry. J Gerontol 1956; 11(3): 298-300. https://doi.org/10.1093/geronj/11.3.298

[11] National Center for Complementary and Integrative Health. Antioxidants and Health. [cited 2016 Dec 25]: Available from: https://nccih.nih.gov/sites/nccam.nih.gov/files/Antioxidants_0 9-15-2015.pdf

[12] Salah MB, Abdelmelek H, Abderraba M. Study of phenolic composition and biological activities assessment of Olive leaves from different varieties grown in Tunisia. Med chem 2012; 2: 107-111.

[13] Gupta C, Prakash D. Nutraceuticals for geriatrics. J Tra Comp Medicine 2015; 2(1): 5-14 https://doi.org/10.1016/j.jtcme.2014.10.004

[14] Hossain MS, Uddin MS, Asaduzzaman M, Munira MS, Uddin MJ, Rafe MR, et al. Inquiry of analgesic and antiinflammatory activities of Xanthosoma sagittifolium leaves. $J$ Coast Life Med 2017; 5(1): 22-26. https://doi.org/10.12980/jclm.5.2017J6-229

[15] Ntie-Kang F, Lifongo LL, Mbaze LM, Ekwelle N, Owono LCO, Megnassan E, et al., Cameroonian medicinal plants: A bioactivity versus ethnobotanical survey and chemotaxonomic classification. BMC Comp Alt Medi 2013; 13(147): 1-3.

https://doi.org/10.1186/1472-6882-13-147

[16] Uddin MS, Asaduzzaman M, Mamun AA, Iqbal MA, Wahid F, et al. Neuroprotective Activity of Asparagus racemosus Linn. against ethanol-induced cognitive impairment and oxidative stress in rats brain: Auspicious for controlling the risk of Alzheimer's Disease. J Alzheimers Dis Parkinsonism 2016; 6(4): 1-10. https://doi.org/10.4172/2161-0460.1000245

[17] Pandey MM, Rastogi S, Rawat AKS. Indian traditional Ayurvedic system of medicine and nutritional supplementation. Evid Based Complement Alternat Med 2013; 2013: 1-12.

https://doi.org/10.1155/2013/376327
[18] Ethnobotany Database of Bangladesh. Gnaphalium luteoalbum L. [cited 2016 Dec 25]: Available from: http://www.mpbd.info/plants/gnaphalium-luteo-album.php

[19] Sarker K, Islam R, Uddin MZ, Hassan MA. Angiosperm flora of Manikgonj sadar upazila, Bangladesh. J Asiat Soc Bangladesh Sci 2013; 39(2): 147-166.

[20] Yusuf M, Chowdhury JU, Haque MN, Begum J. Medicinal Plants of Bangladesh. 2nd ed. Bangladesh: Bangladesh Council of Scientific and Industrial Research; 2009.

[21] Zheng X, Wang W, Piao H, Xu W, Shi H, Zhao C. The genus Gnaphalium L. (Compositae): Phytochemical and pharmacological characteristics. Molecules 2013; 15;18(7): 8298-318

[22] Sofowora A. Medicinal plants and traditional medicinal in Africa. 3rd ed. Nigeria: John Wiley; 1982.

[23] Choi HY, Jhun EJ, Lim BO, Chung IM, Kyung SH, Park DK. Application of flow injection-chemiluminescence to the study of radical scavenging activity in plants. Phytother Res 2000; 14: $250-3$.

https://doi.org/10.1002/1099-1573(200006)14:4<250::AIDPTR587>3.0.CO;2-J

[24] Kunchandy E, Rao MNA. Oxygen radical scavenging activity of Curcumin. Int J Pharm 1990; 58: 237-40.

https://doi.org/10.1016/0378-5173(90)90201-E

[25] Rai S, Wahile A, Mukherjee K, Saha BP, Mukherjee PK. Antioxidant activity of Nelumbo nucifera (sacred lotus) seeds. J Ethnopharmacol 2006; 104: 322-327. https://doi.org/10.1016/j.jep.2005.09.025

[26] Prieto P, Pineda M, Aguilar M. Spectrophotometric quantitation of antioxidant capacity through the formation of a phosphomolybdenum complex: Specific application to the determination of vitamin E. Anal Biochem 1999; 269: 337-41. https://doi.org/10.1006/abio.1999.4019

[27] Singleton VL, Rossi JA. Colorimetry of total phenolics with phosphomolybdic-phosphotungstic acid reagents. Am J Enol Viticulture 1965; 16: 144-58.

[28] Chang C, Yang M, Wen H, Chern J. Estimation of total flavonoids content in propolis by two complementary colorimetric methods. J Food Drug Anal 2002; 10: 178-82.

[29] Lobo V, Patil A, Phatak A, Chandra N. Free radicals, antioxidants and functional foods: Impact on human health. Pharmacogn Rev 2010; 4(8): 118-126. https://doi.org/10.4103/0973-7847.70902

[30] Hossain MS, Asaduzzaman M, Uddin MS, Noor MAA, Rahman MA, Munira MS. Investigation of the in vitro antioxidant and cytotoxic activities of Xanthosoma sagittifolium leaf. Indo Ame J Pharma Res 2015; 5(10): 3300.

[31] Iqbal E, Salim KA, Lim LB. Phytochemical screening, total phenolics and antioxidant activities of bark and leaf extracts of Goniothalamus velutinus (Airy Shaw) from Brunei Darussalam. J King Saud Uni-Sci 2015; 27(3): 224-32. https://doi.org/10.1016/j.jksus.2015.02.003

[32] Dorman HD, Kosar M, Kahlos K, Holm Y, Hiltunen R. Antioxidant properties and composition of aqueous extracts from Mentha species, hybrids, varieties, and cultivars. J Agric Food Chem 2003; 51(16): 4563-9. https://doi.org/10.1021/jf034108k

[33] Dai J, Mumper RJ. Plant phenolics: Extraction, analysis and their antioxidant and anticancer properties. Molecules 2010; 15(10): 7313-7352. https://doi.org/10.3390/molecules 15107313

[34] Pandey KB, Rizvi SI. Plant polyphenols as dietary antioxidants in human health and disease. Oxidative Med Cellular Longe 2009; 2(5): 270-278. https://doi.org/10.4161/oxim.2.5.9498

[35] Uddin MS, Mamun AA, Khanum S, Begum Y, Alam MS. Analysis of in vitro antioxidant activity of Caryota urens L. leaves: A traditional natural remedy. J Coast Life Med 2016; 4(6): 483-484.

https://doi.org/10.12980/jclm.4.2016J6-65 
[36] Khatoon M, Islam E, Islam R, Rahman AA, Alam AHMK, Khondkar $\mathrm{P}$, et al. Estimation of total phenol and in vitro antioxidant activity of Albizia procera leaves. BMC Res Notes 2013; 6: 121.

https://doi.org/10.1186/1756-0500-6-121

[37] Saeed N, Khan MR, Shabbir M. Antioxidant activity, total phenolic and total flavonoid contents of whole plant extracts Torilis leptophylla L. BMC Complement Altern Med 2012; 12(221): 2-10.

https://doi.org/10.1186/1472-6882-12-221

[38] Helmut S. Strategies of antioxidant defense. Eur J Biochemistry 1993; 215(2): 213-219. https://doi.org/10.1111/j.1432-1033.1993.tb18025.x

[39] Boehm D, Heslin C, Cullen PJ, Bourke P. Cytotoxic and mutagenic potential of solutions exposed to cold atmospheric plasma. Sci Rep 2016; 6:1-14.

https://doi.org/10.1038/srep21464

[40] Miyamoto S, Martinez GR, Medeiros MH, Di Mascio P. Singlet molecular oxygen generated by biological hydroperoxides. J Photochem Photobiol B 2014; 139: 24-33. https://doi.org/10.1016/j.jphotobiol.2014.03.028

[41] Rahman MM, Islam MB, Biswas M, Alam AHMK. In vitro antioxidant and free radical scavenging activity of different parts of Tabebuia pallida growing in Bangladesh. BMC Res Notes 2015; 8(621): 2-5. https://doi.org/10.1186/s13104-015-1618-6

[42] Mayer B, Hemmens B. Biosynthesis and action of nitric oxide in mammalian cells. Trends Biochem Sci 1997; 22: 477-481. https://doi.org/10.1016/S0968-0004(97)01147-X

[43] Hou YC, Janczuk A, Wang PG. Current trends in the development of nitric oxide donors. Cur Pharma Design 1999; 5(6): 417-41.

[44] Heales SJR, Bolanos JP, Stewart VC, Brookes PS, Land JM, Clark JB. Nitric oxide, mitochondria and neurological disease. Biochim Biophys Acta 1999; 1410: 215-228. https://doi.org/10.1016/S0005-2728(98)00168-6

[45] Hirsch EC, Hunot S. Nitric oxide, glial cells and neuronal degeneration in parkinsonism. Trends Pharmacol Sci 2000; 21: 163-165.

https://doi.org/10.1016/S0165-6147(00)01471-1

[46] Huang D, Ou B, Prior RL. The chemistry behind antioxidant capacity assays. J Agric Food Chem 2005; 53(6): 1841-56. https://doi.org/10.1021/jf030723c

[47] Kumar S, Sandhir R, Ojha S. Evaluation of antioxidant activity and total phenol in different varieties of Lantana camara leaves. BMC Res Notes 2014; 7: 560. https://doi.org/10.1186/1756-0500-7-560
[48] Sharififar F, Dehghn-Nudeh G, Mirtajaldini M. Major flavonoids with antioxidant activity from Teucrium polium $\mathrm{L}$. Food Chem 2009; 112: 885-888. https://doi.org/10.1016/.j.foodchem.2008.06.064

[49] Khan RA, Khan MR, Sahreen S. Assessment of flavonoids contents and in vitro antioxidant activity of Launaea procumbens. Chem Central J 2012; 6: 43. https://doi.org/10.1186/1752-153X-6-43

[50] Oktay M, Gülçin I, Küfrevioglu OI. Determination of in vitro antioxidant activity of fennel (Foeniculum vulgare) seed extracts. LWT-Food Sci Technol 2003; 36: 263-271. https://doi.org/10.1016/S0023-6438(02)00226-8

[51] Saeed N, Khan MR, Shabbir M. Antioxidant activity, total phenolic and total flavonoid contents of whole plant extracts Torilis leptophylla L. BMC Complement Altern Med 2012; 12: 221.

https://doi.org/10.1186/1472-6882-12-221

[52] Balasundrama N, Sundramb K, Samman S. Phenolic compounds in plants and agri -industrial by-products: Antioxidant activity, occurrence, and potential uses. Food Chem 2006; 99(1): 191-203.

https://doi.org/10.1016/j.foodchem.2005.07.042

[53] Dixon RA, Dey PM, Lamb CJ. Phytoalexins: Enzymology and molecular biology. Adv Enzy Rel Areas Mole Bio 1983; 55: 1136. https://doi.org/10.1002/9780470123010.ch1

[54] Alam B, Akter F, Parvin N, Sharmin Pia R, Akter S, Chowdhury $\mathrm{J}$, et al. Antioxidant, analgesic and antiinflammatory activities of the methanolic extract of Piper betle leaves. Avicenna J Phytomed 2013; 3(2): 112-25.

[55] Kumar S, Pandey AK. Chemistry and biological activities of flavonoids: An overview. Scientific World J 2013; 2013: 1-16. https://doi.org/10.1155/2013/162750

[56] Nijveldt RJ, van Nood E, van Hoorn D EC, Boelens PG, van Norren K, van Leeuwen PAM. Flavonoids: A review of probable mechanisms of action and potential applications. Am J Clin Nutr 2001; 74: 418-25.

[57] Hassan RA. Biochemical studies on Gnaphalium luteo-album L. 2.-Flavonoids content [Egypt]. [cited 2016 Dec 25] Available from: http://agris.fao.org/agrissearch/search.do?recordID=EG9000662 